\title{
THE EFFORTS TO IMPROVE THE ACTIVITIES OF LEARNING MATHEMATICS USING COOPERATIVE LEARNING MODELS OF NHT TYPE IN SMP MUHAMMADIYAH 2 MLATI
}

\author{
Mayang Faulina ${ }^{a}$, Sumargiyani ${ }^{\mathrm{b}}$ \\ Program Studi Pendidikan Matematika Universitas Ahmad Dahlan \\ Jalan Ring Road Selatan, Tamanan, Banguntapan, Bantul Yogyakarta \\ amayang13faulina@gmail.com, ${ }^{\text {b sumargiyani04@yahoo.com }}$
}

\begin{abstract}
Learning that does not involve active student participation can influence student activities, especially in mathematics learning using NHT type cooperative learning models. This study aims to determine an increase in the activity of learning mathematics in class VII D students in the even semester of SMP Muhammadiyah 2 Mlati in the 2015/2016 academic year by using the NHT type of cooperative learning model. This research is a Classroom Action Research (CAR). The setting used is class VII D, amounting to 30 students. The research plan is carried out in 3 Cycles and complete in Cycle III. In Cycle I consisted of 1 meeting, Cycle II consisted of 2 meetings, and Cycle III consisted of 1 meeting. Each Cycle uses NHT type cooperative learning models. Data collected by observation, interview and documentation. Analysis of the data used is qualitative descriptive analysis. The results showed that mathematics learning using the NHT type of cooperative learning model could increase the learning activity of students of class VII D even semester of SMP Muhammadiyah 2 Mlati, Sleman Regency Academic Year 2015/2016. This is evident from the increase in student learning activities. In Cycle I, Cycle II and Cycle III that use the NHT type of cooperative learning model experienced an increase in which the first cycle the average percentage of student activity was $37.92 \%$ with poor criteria, the average percentage of activeness in cycle II was $52.5 \%$ with sufficient criteria and the average percentage of activeness in cycle III is $65.28 \%$ with good criteria.
\end{abstract}

Keywords: Activities, Cooperative Learning, NHT.

\section{INTRODUCTION}

The current condition of the Indonesian state is experiencing very significant developments. These developments can be seen by the variety of technologies and natural conditions that greatly affect patterns of daily life. Likewise with the level of education that must still be developed to progress the quality and quality of education so that it gets better. Education can be seen from student achievement, while student achievement depends on the teaching and learning process carried out at school. The process of teaching and learning activities must involve all components of teaching, these teaching components can determine goals in learning, as according to Djamarah, Syariful Bahri (2010: 44) teaching and learning activities are the core activities in education. Everything that has been programmed will be implemented in the teaching and learning process. In the teaching and learning process will involve all components of teaching, teaching and learning activities will determine the extent to which the goals set can be achieved. One important problem in the world of education is the problem of the success of the teaching and learning process. The results of this education will be considered high quality if the abilities, knowledge, attitudes, and skills possessed by students can be useful for further development both in the world of work or society. The learning process is often found that the role of a teacher as an educator is maximized in teaching, because in the learning process commonly used so far using the expository method. Learning that leads to the delivery of lesson content to students directly, because the teacher conveys in the form of lectures, demonstrations, questions and answers and assignments. Then students follow the pattern set by the teacher. But students are passive and less involved in learning, so learning outcomes have not been maximized.

The low completeness of the results of learning mathematics can be shown from the acquisition of Daily Test scores obtained by class VII SMP Muhammadiyah 2 Mlati there are some students who have not met the Minimum completeness Criteria (MCC) mathematics subjects 75. Some students still look less active and enthusiastic in participating in mathematics learning. Whether or not learning outcomes obtained by students are influenced by learning activeness, where if the learning activeness is 
good then the results obtained will be good too. Likewise with student learning that must be improved, According to Sudjana, Nana (1989: 5) learning is a process that is marked by changes in a person. Especially in learning mathematics, according to Schenfeld in Hamzah B Uno (2007: 130) defines that "Learning mathematics is an activity relating to the selection of sets of simple mathematical elements and is a new set of more complicated. And so on, so in learning, mathematics must be done hierarchically. In other words, learning mathematics at a higher stage must be based on a lower stage. Likewise with the activeness of student learning, according to the Directorate of High School Development (2010: 58), the activeness of students in learning can be seen simply from the efforts of students, namely: a. Enthusiastic students in participating in learning, b. Student interaction with the teacher, c. Interaction between students, d. Group collaboration, e. Student activities in groups, f. Student participation in concluding the results of the discussion. Therefore, to create active learning principles, teachers need to have the skills to interact with students and choose the right learning model to deliver material so students can be active in learning activities at school.

Learning by using cooperative methods, Cooperative Learning itself is a learning strategy that prioritizes cooperation between students in groups to achieve learning goals. According to Lie, A (2008: 31) said that as for the five elements of the cooperative learning model are a) Positive interdependence, b) Individual responsibility, c) Face to face, d) Communication between members and, e) Evaluation of group processes. In using the cooperative method allows students to achieve success in learning and can also train students to have thinking skills and social skills, such as the ability to express opinions, accept advice from others and work together, so students are increasingly trained to solve a problem. Likewise to make students active is to use a group discussion learning model. This learning model will activate students in the teaching and learning process which can lead to student interaction with the teacher. One of the cooperative learning that can be used in learning is the type of Number Heads Together (NHT) ". Number Heads Together (NHT) is an approach developed by Spencer Kagan (to involve more students in reviewing various materials discussed in a lesson and to check their understanding of the content of the lesson (Arends, Richard I. 2008: 16) ".

The NHT on every member in one group must understand and comprehend the solution to the problem given. NHT type cooperative learning makes it possible to be actively involved in developing knowledge, attitudes, and skills. It also can create conditions for effective learning and actively collaborate in learning activities. NHT consists of four phases, namely numbering, assigning tasks, thinking together and answering. NHT type cooperative learning model is a learning model that involves many students in studying the material included in a learning and checking student understanding of the contents of the lesson. The steps in using the NHT learning model according to Lie, Anita (2008: 60), namely: 1) Students are divided into groups, each student in each group gets a number, 2) The teacher gives the assignment and each group works on it, 3) The group decide on the answer that is considered the most correct and make sure each group member knows this answer, 4) The teacher calls one of the numbers. Students with the numbers called report the results of their collaboration. "

The NHT type of cooperative learning model has the advantage of making students serious in discussions, increasing enthusiasm and cooperation and making students better prepared in understanding the lesson. The NHT type of cooperative learning model is basically a variation of group discussion with the characteristic that the teacher only appoints a student who represents his group without first telling who is representing the group. So this method encourages the involvement of all students. This is the reason the author chose to apply the NHT type of learning model.

\section{METHODS}

This research is classroom action research. Classroom Action Research (CAR) or Classroom Action Research (CAR) according to Arikunto, Suharsimi, et al (2006: 3) this class action research is an examination of learning activities in the form of an action, which is deliberately raised and occurs in a 
class together. The action is given by the teacher or with direction from the teacher done by students. The following explanation of the research steps:

\section{a. Cycle I}

1. Planning

At this stage, the researcher designs the actions that will be carried out by the research, including:

a) Make a Learning Plan (LP) and Student Worksheet (WS) about the material to be taught using the NHT type of cooperative learning model that will be used.

b) Arrange and prepare observation sheets regarding the learning carried out.

c) Arrange interview guidelines for students to find out how active student learning is towards learning.

d) Making research instruments that include evaluation tools in the form of observation sheets and interviews.

2. Implementation

Activities that have been designed at the planning stage are implemented at the implementation stage. In this implementation phase, the researcher acts as a mathematics teacher in class VII D and carries out the learning activities as previously planned, namely the NHT type cooperative learning model, while the teaching steps are as follows:

a) Students are divided into groups of 5-6 students. Each student in each group gets a number.

b) The teacher gives the task and each group to work on.

c) The group decides which answer is considered the most correct and ensures that each group member knows the answer.

d) The teacher calls one number. Students with the numbers called report the results of their collaboration.

After completing the assignment from the researcher, they will discuss and conclude together. During implementation, according to the flexible nature of the plan, the plan can change according to the conditions on the ground.

3. Observing

Observation activities are carried out to find out things that happen when learning takes place. This research observer of learning activities based on the observation sheet that has been prepared is the active observation sheet for the teacher and the active observation sheet for students filled in by the observer, the mathematics teacher in class VII D.

4. Reflexive

This stage the researcher together with the teacher looks back on what the researcher has done, then discusses, evaluates and considers the good or bad actions that have been taken. At this stage, the results obtained at the observation stage are collected and then analyzed. The results of these data will be seen whether it meets the expected targets in the mastery learning that has been set. If it does not meet the target, then the research continues to the next cycle. Deficiencies in the first cycle will be corrected in the next cycle, namely, cycle II.

\section{b. Cycle II}

The activity in cycle II is a reflection of the cycle I stage. This cycle II is the work carried out following cycle I. The actions in cycle II are arranged based on the reflection of cycle I.

\section{Planning}

At this stage the researcher designs actions to be taken in the study, including:

a) Make a Learning Implementation Plan (RPP) and Student Worksheet (LKS) about the material to be taught using the NHT type of cooperative learning model that will be used.

b) Arrange and prepare observation sheets that will be used in each lesson.

c) Making research instruments that include evaluation tools in the form of diagnostic tests. 
d) Develop interview guidelines for students to find out how students respond to learning that has been carried out.

It also formulated learning actions that refer to the results of the first cycle with the aim of correcting the weaknesses found and maintaining the success achieved in cycle I.

2. Acting

Activities carried out in the implementation of the action that is improving in cycle I. Group learning is still constant and the material given is repeating the sub-topics of discussion in the first cycle working on the worksheet, then the results of group collaboration.

3. Observing

This stage is carried out with the implementation phase of the action. When the activity is carried out, record the things that happened during the implementation of the action. The things observed during learning are the activeness of students in cooperative learning of the NHT type, to help the implementation of observations, observation sheets are used. Observation can be used as a reflexive material.

4. Reflection

The activity carried out was a discussion between researchers and mathematics teachers regarding the results of observations and changes after the NHT type cooperative learning model. As well as considering the next cycle, if in cycle II there are still results that have not reached better than the first cycle, followed by cycle III.

\section{c. Cycle III}

At the stage of cycle III, this is done if in the phase II cycle has not yet achieved good results, so that further action is still needed. The action plan for the third cycle is based on the results of the analysis in Cycle II and it is expected that in Cycle III it can improve and improve activities in Cycle I and II. The data obtained in the study are the results of observations, interviews, and the results of daily tests.

1. Observation sheet

Observation guidelines to focus observations on student activeness in students' teaching and learning activities using the NHT type learning model. The criteria for the P-value can be seen in the following table:

Table 1. Student Activity Criteria

\begin{tabular}{|c|c|}
\hline Interval Score & Criteria \\
\hline $0 \% \leq P \leq 20 \%$ & Very, very little \\
\hline $20 \%<P \leq 40 \%$ & Less \\
\hline $40 \%<P \leq 60 \%$ & Enough \\
\hline $60 \%<P \leq 80 \%$ & Well \\
\hline $80 \%<P \leq 100 \%$ & Very well \\
\hline
\end{tabular}

(Source: Suharsimi Arikunto dan Cepi Safruddin.A.J.2004:19)

From the results of observations of student activeness data can be seen the number of active students for each indicator. While the percentage of research success can be calculated using the formula:

$$
P=\frac{S_{k}}{S_{m}} \times 100 \%
$$

Information :

P : : Percent of student activity

$\mathrm{S}_{\mathrm{k}} \quad$ : Overall score obtained

$\mathrm{S}_{\mathrm{m}} \quad$ : The maximum score obtained

2. Analysis and Interview

The results of interviews with students and teachers then analyzed according to the interview guidelines used. In order to obtain data about the advantages of learning through NHT type 
cooperative learning and know the responses of students and teachers to the NHT type cooperative learning process.

3. Analysis of the end of the test cycle

From the end of the cycle, the test can be obtained about individual student learning completeness with the learning completeness guidelines meeting a minimum score of 75 in accordance with the KKM set by the school.

\section{RESULTS}

Based on research conducted starting from cycle I, cycle II and cycle III regarding mathematics learning by applying the NHT type cooperative learning model in SMP Muhammadiyah 2 Mlati Sleman in the academic year of 2015/2016 class VII D showed an increase in students' learning activeness in mathematics learning. This can be seen from the analysis of the results of active observations and results of student interviews. In cycle I, cycle II and cycle III which increased. The average percentage of indicators of student activity in the first cycle for students' enthusiasm in participating in learning was $38.33 \%$, student interaction with teachers was $37.5 \%$, interaction between students was $38.33 \%$, group collaboration was $39.17 \%$, activity students in groups of $35.00 \%$, and student participation in concluding the results of the discussion amounted to $39.17 \%$.

In cycle II after correcting the deficiencies found in cycle II, activeness increases. The average percentage of the indicators of student activity in the second cycle for enthusiastic students in participating in learning amounted to $57.50 \%$, interaction between students and teachers amounted to $56.30 \%$, interaction between students amounted to $53.33 \%$, group collaboration amounted to $48.30 \%$, activities students in groups of $47.50 \%$, and student participation in concluding the results of the discussion of $52.10 \%$.

In cycle III after correcting the deficiencies found in cycle II, the activeness of students increases with good criteria. The average percentage of indicators of student activity in the third cycle for students' enthusiasm in participating in the learning was $67.50 \%$, student interaction with teachers was $60.83 \%$, interaction between students was $63.33 \%$, group cooperation was $66.67 \%$, activity students in groups of $60.00 \%$, and student participation in concluding the results of the discussion amounted to $73.33 \%$. Analysis of the percentage of observations of student activity in cycle I, cycle II and cycle III can be seen in the table.

Table 2. Increased percentage of observations

\begin{tabular}{|c|l|c|c|c|c|}
\hline No & \multicolumn{1}{|c|}{ Indicator } & Cycle I \% & Cycle II \% & Cycle III \% & Info \\
\hline 1. & $\begin{array}{l}\text { Enthusiastic students } \\
\text { participate in learning }\end{array}$ & $38,33 \%$ & $57,50 \%$ & $67,50 \%$ & Increased \\
\hline 2. & $\begin{array}{l}\text { Student interaction with } \\
\text { the teacher }\end{array}$ & $37,50 \%$ & $56,3 \%$ & $60,83 \%$ & Increased \\
\hline 3. & $\begin{array}{l}\text { Student interaction with } \\
\text { students }\end{array}$ & $38,33 \%$ & $53.3 \%$ & $63,33 \%$ & Increased \\
\hline 4. & $\begin{array}{l}\text { Student interaction with } \\
\text { students }\end{array}$ & $39,17 \%$ & $48,3 \%$ & $66,67 \%$ & Increased \\
\hline 5. & $\begin{array}{l}\text { Student activities in } \\
\text { groups }\end{array}$ & $35,00 \%$ & $47,5 \%$ & $60,00 \%$ & Increased \\
\hline 6. & $\begin{array}{l}\text { Student participation in } \\
\text { concluding the results of } \\
\text { the discussion }\end{array}$ & $39,17 \%$ & $52,15 \%$ & $73,33 \%$ & Increased \\
\hline & Average & $37,92 \%$ & $52,2 \%$ & $65,28 \%$ & Increased \\
\hline
\end{tabular}

For more details, presented in the following graphical form: 


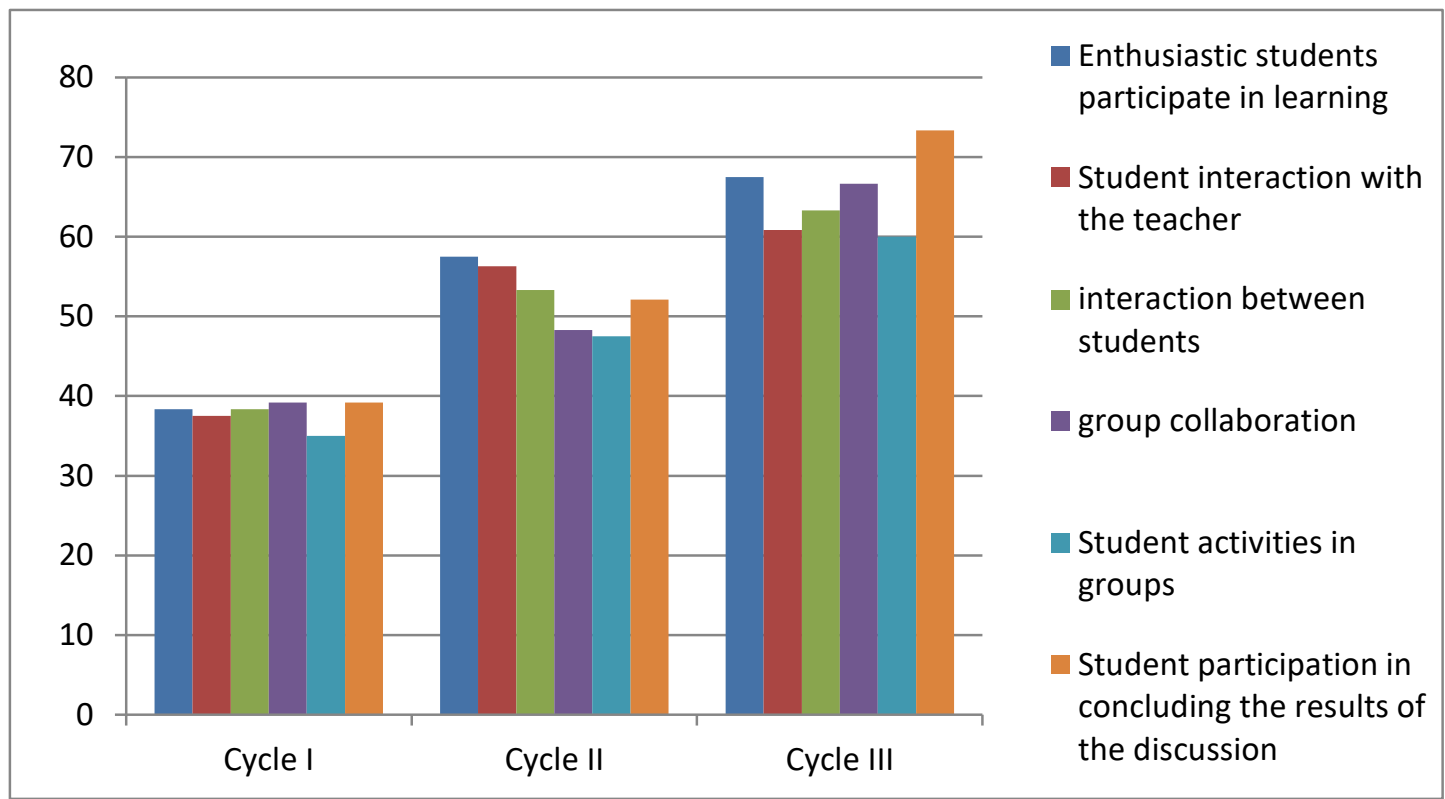

Graph 1. Observation Graph Results of Increased Student Activity in All Cycles.

From the overall data above, the research objectives have been achieved in the third cycle, so the research is considered complete and the research results show an increase in student activity in participating in learning mathematics. This can be seen from the increase in student activity in learning mathematics by using NHT type cooperative learning.

In this study, in addition to using data from observations researchers also used data in the form of interviews conducted with mathematics teachers in class VII D and representatives of class VII D students at the end of cycle I, cycle II and cycle III. Interviews were conducted to determine teacher and student responses regarding the NHT type of cooperative learning model and student activity during the learning process. The results of interviews with students obtained that students look more active, happy and not boring in learning mathematics. For more details on the results of students, interviews can be seen in appendix 4.17 .

Overall, it can be concluded that mathematics learning by using NHT type cooperative learning can be used as an effort to increase student activity in learning mathematics in class VII D even semester of SMP Muhammadiyah 2 Mlati in the academic year 2015/2016. So the action hypothesis in this study was accepted.

\section{CONCLUSION}

Based on the results of research and discussion, it can be concluded that the application of the NHT type of cooperative learning model can increase the activity of Grade VII D students of Muhammadiyah 2 Mlati Middle School in the academic year 2015/2016. This is shown from the results of observations of student activity and is strengthened by the results of student interviews. The results of observations of student activity increased from cycle 1 to cycle II by $14.58 \%$ and from cycle II to cycle III by $12.78 \%$. The average percentage of activeness of students in the first cycle was $37.92 \%$ with the criteria "Poor", the second cycle was 52.5\% with the criteria "Enough" and in the third cycle was $65.28 \%$ with the criteria "Good". Thus the results of the comparison between the results that have been achieved with the targets set, have shown optimal results.

\section{REFERENCES}

Arends, Richard I.2008. Learning To Teach.Yogyakarta: Pustaka Pelajar.

Arikunto, Suharsimi dkk. 2012. Penelitian Tindakan Kelas. Jakarta: PT Bumi Aksara

Arikunto, Suharsimi dan Cepi Safruddin A.j dkk. 2012. Penelitian Tindakan Kelas. Jakarta: PT Bumi Aksara

Direktorat Pembinaan SMA. 2010. Petunjuk Teknis Penyusunan Perangkat Penilaian Afektif di SMA. 
Djamarah, Syaiful Bahri dan Zain, Aswan . 2010. Strategi Belajar Mengajar. Jakarta : Rineka Cipta. Lie, A. 2008. Mempraktekkan Cooperatif Learning di Ruang-ruang Kelas. Jakarta: PT. Grasindo Remaja Rosdakarya.

Sudjana, Nana. 1989. CBSA Cara Belajar Siswa Aktif Dalam Proses Belajar Mengajar. Bandung: Sinar Baru

Uno, Hamzah B. 2007. Model Pembelajaran Menciptakan Proses Belajar Mengajar yang Kreatif dan Efektif. Jakarta : Bumi Aksara 